\title{
MODELLING SOIL EROSION AND SEDIMENT TRANSPORT UNDER DIFFERENT LAND MANAGEMENT OPTIONS IN A SOUTHERN-ITALY WATERSHED
}

\author{
I. ABUIZIAH, T. BISANTINO, F. GENTILE \& G. TRISORIO LIUZZI \\ Dipartimento di Scienze Agro-Ambientali e Territoriali - DISAAT, University of Bari “A. Moro", \\ Via Amendola 165/A 70126 Bari, Italy.
}

\begin{abstract}
The aim of this study is to investigate the influence of different land management options on the sediment load at the watershed scale. To reach this, the Annualized agricultural non-point source model was used in the Candelaro basin $\left(2300 \mathrm{~km}^{2}\right)$. The watershed is located in a semi-arid area of southern Italy (Puglia region) and is affected by extensive erosion processes on the hillslopes. The sediment transport simulations have been compared with the 15 years (1970-1984) data coming from measures taken in two sub-watersheds (Vulgano and Salsola). Later, the model has been applied for a period of 24 years (1985-2008) to evaluate the effects of different land management options on the sediment yield: traditional best management practices, environmentally targeted agricultural practices and water and soil conservation works. The results obtained in the first part of the work show that the Annualized agricultural non-point source model performs well in simulating runoff and sediment yields at the watershed scale. Furthermore, the analysis carried out shows that the model is an efficient tool to assess the influence of different management options in the long term and in different weather conditions.

Keywords: AnnAGNPS model, sediment yield, soil erosion, surface runoff, watershed management options.
\end{abstract}

\section{INTRODUCTION}

Water quality and quantity is certainly the most challenging current and future natural issue, especially in the arid and semi-arid regions. Water management is the most critical issue as it impacts the livelihood of people and the productivity of the land. Hydrological and erosive models form the basis for decisions regarding the development and management of water and land resources in a watershed. During the past four decades, a number of simulation models have been developed to aid in the understanding and management of surface runoff, sediment and nutrient transport processes. The widely used water quality models include ANSWERS [1], Annualized agricultural non point source (AnnAGNPS) [2], EPIC [3] and SWAT [4].

The AnnAGNPS model was originally developed by the U.S. Department of Agriculture, Agricultural Research Service in cooperation with the Minnesota Pollution Control Agency and the Soil Conservation Service for the analysis of large agricultural watersheds ranging in size between 500 and 23,000 acres. The model was developed to analyze and provide estimates of runoff with primary emphasis upon sediment and nutrients transport from agricultural watersheds and to compare the effects of various conservation alternatives. AnnAGNPS was calibrated, validated and applied for runoff and sediment yield in different geographic locations, conditions and management practices [5-8]. The impact of the variation of the most meaningful parameters $[\mathrm{R}, \mathrm{K}, \mathrm{C}$ and $\mathrm{P}$ factors of the universal soil loss equation (USLE), curve number $(\mathrm{CN})$ and Manning's roughness coefficient $(\mathrm{MN})]$ on the model response was evaluated in several works $[9,10]$. In semi-arid environments the model has been tested at different spatial and time scales [11]. The model was calibrated and validated in northern Puglia (southern Italy) watersheds at event scale using 12 flood events, and in the long-term using 10 years of runoff data [12]. 
In this article the model was used in the Candelaro watershed (northern Puglia-southern Italy) to simulate the runoff and sediment yield and to assess the impact of different land management practices. The study area is characterized by water availability insufficient to satisfy the irrigation demands and by an increasing groundwater exploitation that is used to compensate the supply deficit.

In order to determine the most suitable management practice, the effectiveness of the following conservation programs was assessed: the introduction of agricultural best management practices (BMPs) such as no-till plant; the employment of environmentally targeted agricultural practices such as vegetated streams; and the use of water and soil conservation works such as reservoirs. The effects of each factor individually and of their different combinations were evaluated. Agricultural BMPs aim at maintaining a good soil structure, which is a result of management systems and include the regular use of soil-improving crops, the use of organic mulches during the critical stage of plant establishment and tillage practices that avoid unnecessary breakdown of soil structure. Significant improvements in water quality in agricultural watersheds could be achieved employing environmentally targeted practices, which consist of additional management practices such as riparian buffers, engineered wetlands, grassed waterways, filter strips and field borders. These practices improve water quality by reducing the amount of sediments reaching watercourses. Water and soil conservation works are hillslope works, reducing surface runoff and increasing local infiltration, and reservoirs collecting headwater flow and providing supplemental water for irrigation [13, 14].

\section{MATERIAL AND METHODS}

\subsection{The Candelaro watershed}

The Candelaro torrent is one of the main water courses of the Puglia region (Fig. 1). It is located in the northern part of the region on the typical geo-morphological environment of the Tavoliere plain (the largest alluvial plain in southern Italy and the second one in Italy). The surface area is $2330 \mathrm{~km}^{2}$, the mean elevation is $300 \mathrm{~m}$ a.s.l. and the maximum elevation is $1150 \mathrm{~m}$ a.s.l.

The climate, generally defined as semi-arid Mediterranean, is warm and dry, but in large areas of the plain it is characterized by torrid summers and cold winter temperatures that often fall beneath zero. In the coastal belt, the sea exercises a mitigating action and consequently the winters are less rigid and the summers are less hot. The rainfall, concentrated in the OctoberApril period, is scarce $(\sim 500 \mathrm{~mm}$ per year). Flash floods are not rare. A particular climatic characteristic of the area is the high value of mean annual potential evapotranspiration, which ranges between 900 and $1100 \mathrm{~mm}$. The study of the thermo-pluviometric data highlighted that the rainfall rate decreased $\sim 30 \%$ during the last 40 years while the temperature increased $\sim 0.5^{\circ} \mathrm{C}$. This produced an increase in the areas considered subject to the risk of desertification.

The pedology of the Candelaro watershed is almost heterogeneous, due to the different textures and soil compositions. In particular, most of the soils are characterized by the presence of clay and sandy clay. The former are located principally in the flat part of the plain, and their origin is alluvial with low percentage of skeleton, high capacity of water retention and low hydraulic conductivity resulting in a low drainage velocity; the latter have a higher percentage of sand and are settled in the high part of the plain (above $100 \mathrm{~m}$ a.s.l.) and along the Gargano border. These soils are characterized by high hydraulic conductivity, low water retention and a low capacity of retaining nitrogen compounds. 


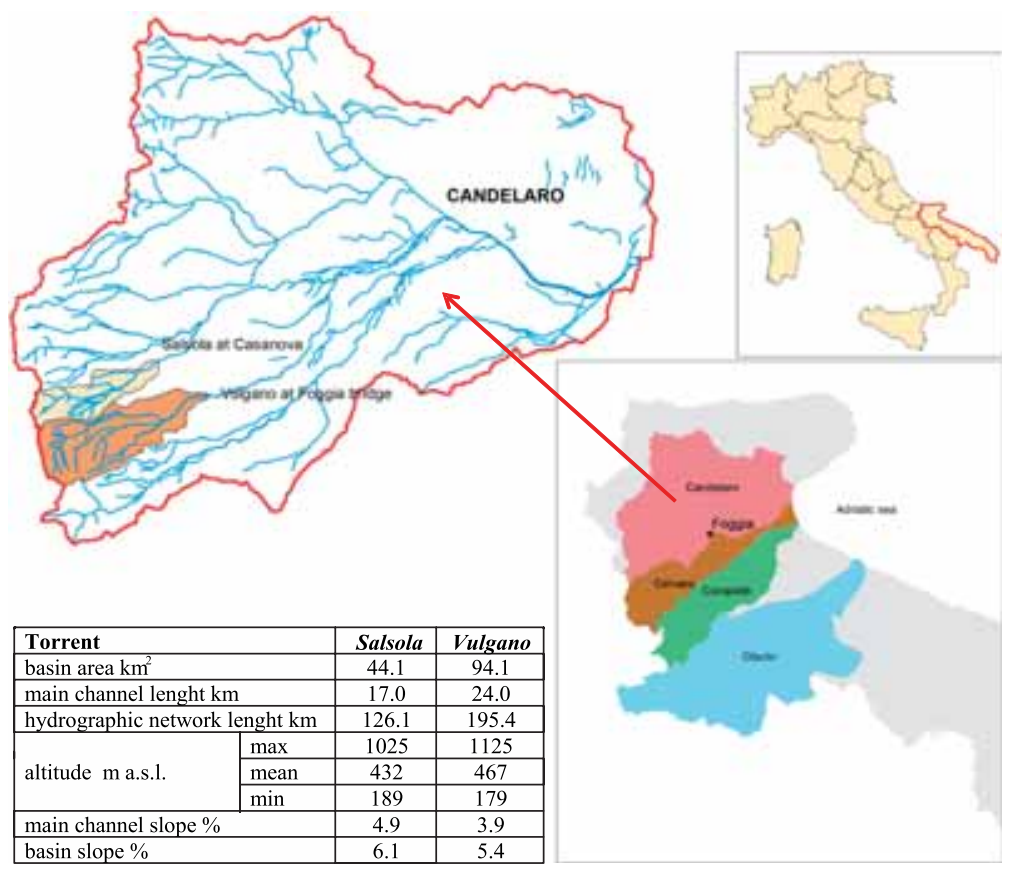

Figure 1: The Candelaro watershed and the two sub-watersheds: Salsola at Casanova and Vulgano at Foggia bridge.

Daily streamflow and monthly sediment transport data for two sub-watersheds (Fig. 1) (Salsola at Casanova and Vulgano at Foggia bridge) were available from the Italian Hydrological Service gauging stations, referred to the period 1970-1984.

\subsection{The AnnAGNPS model}

The AnnAGNPS model is a continuous, distributed model, which can be used to estimate surface runoff, sediment yield and nutrient loading from an agricultural watershed [2]. A set of modules allows for the prediction of non-point source pollution loading within agricultural watersheds and can be used to assist in the creation of BMPs and other planning-related decisions.

The hydrology is based on a simple water-balance approach. Daily soil moisture accounts for runoff, evapotranspiration and percolation, maintaining a water budget in the two-layer soil system. The model computes runoff using the SCS Curve number method. Curve numbers are modified at the daily scale, based on tillage operations, soil moisture and crop stage. The actual evapotranspiration is a function of potential evapotranspiration calculated using the Penman equation [15] and soil moisture content. The peak discharge calculation is based on the concept of unit peak flow of the modified SCS-NRCS TR55 method [16]. Soil erosion is determined using the revised universal soil loss equation (RUSLE). However, sediment yield is computed using the HUSLE [17], and sediment transport is estimated using the Einstein equation and the Bagnold transport capacity.

The model requires several inputs such as land -use, surface conditions, channel data and fertilization. The primary outputs include estimates of runoff volume, peak flow rate at the 
watershed outlet and area-weighted erosion for both upland and channel areas. Further outputs are the sediment delivery ratio, sediment enrichment ratio, mean sediment concentration and the total sediment yield for each of the five sediment particle size classes. The watershed is subdivided into homogenous land areas with respect to the soil type, land-use and management. These areas come from the original square grid cells and have appropriate hydrologic boundaries that are generated by the terrain-following Geographical Information System software.

Several studies on the sensitivity of the model to the different parameters were carried out $[18,19]$. Bisantino et al. [20] in the Carapelle watershed, close to the Candelaro watershed, found that the $\mathrm{CN}$ value is the most sensitive parameter of the model. The $\mathrm{CN}$ mostly affects runoff, through the determination of high variations of runoff for small variations in $\mathrm{CN}$, and also has a dominant effect on peak discharge and sediment load evaluations. The Manning's roughness factor $\mathrm{MN}$ is an important parameter for the calculation of the flow velocity and time of concentration. This parameter has a little impact on runoff, but the effect is moderate on sediment load as the roughness factor is involved both in the peak discharge calculation to derive the sediment delivery ratio and in the estimation of sediment transport. Sediment load also depends on the $\mathrm{K}$ factor and on the root density, surface residue and crown canopy cover associated with the $\mathrm{C}$ factor. The $\mathrm{R}$ factor of the RUSLE had the least effect on the model outputs [20].

\section{RESULTS AND DISCUSSION}

\subsection{Input data preparation}

AnnAGNPS input data used to describe the Candelaro watershed are the elevation map (NASA-DEM 90m), soil data (1:1 00000 ACLA project [21]), land-use (1:1 00000 CORINE Land Cover) and climate data coming from 23 Italian Hydrological Service meteorological stations for the period 1970-1984 (Fig. 2).

The TopAGNPS module was used to determine sub-watersheds, the extent of the watershed boundary, the channel network and the outlet. This module required two parameters: (i) the CSA (critical source area, in ha) is the minimum upstream drainage area below which a source channel is initiated and maintained and (ii) the MSCL (minimum source channel length, in $\mathrm{m}$ ) is the minimum acceptable length for a source channel to exist. These two parameters control the topology and properties of the network and sub-catchments generated by TOPAZ. For example, when the CSA parameter increases, the drainage density of the generated network decreases, and when the MSCL parameter is increased, short source channels (first-order channels) are removed. The CSA and MSCL codes are user-defined parameters that account for spatial variability and in our simulations we set CSA $=50$ ha and $\mathrm{MSCL}=250 \mathrm{~m}$.

Specific databases were built to assign $\mathrm{CN}$ values, hydraulic soil properties, erodibility factors $\mathrm{K}$, rainfall erosivity factor $\mathrm{R}$, crop parameters and in-field operation management practices. Land-uses were grouped in six classes: cropland, rangeland, forest, urban, fallow and pasture. With regard to cropland, individual databases were built for winter wheat, olive groves, vineyards and orchards.

\subsection{Model calibration and validation}

The model was calibrated and validated to current conditions in the Candelaro watershed using monthly runoff and yearly sediment loads in the Salsola and Vulgano sub-watersheds. 


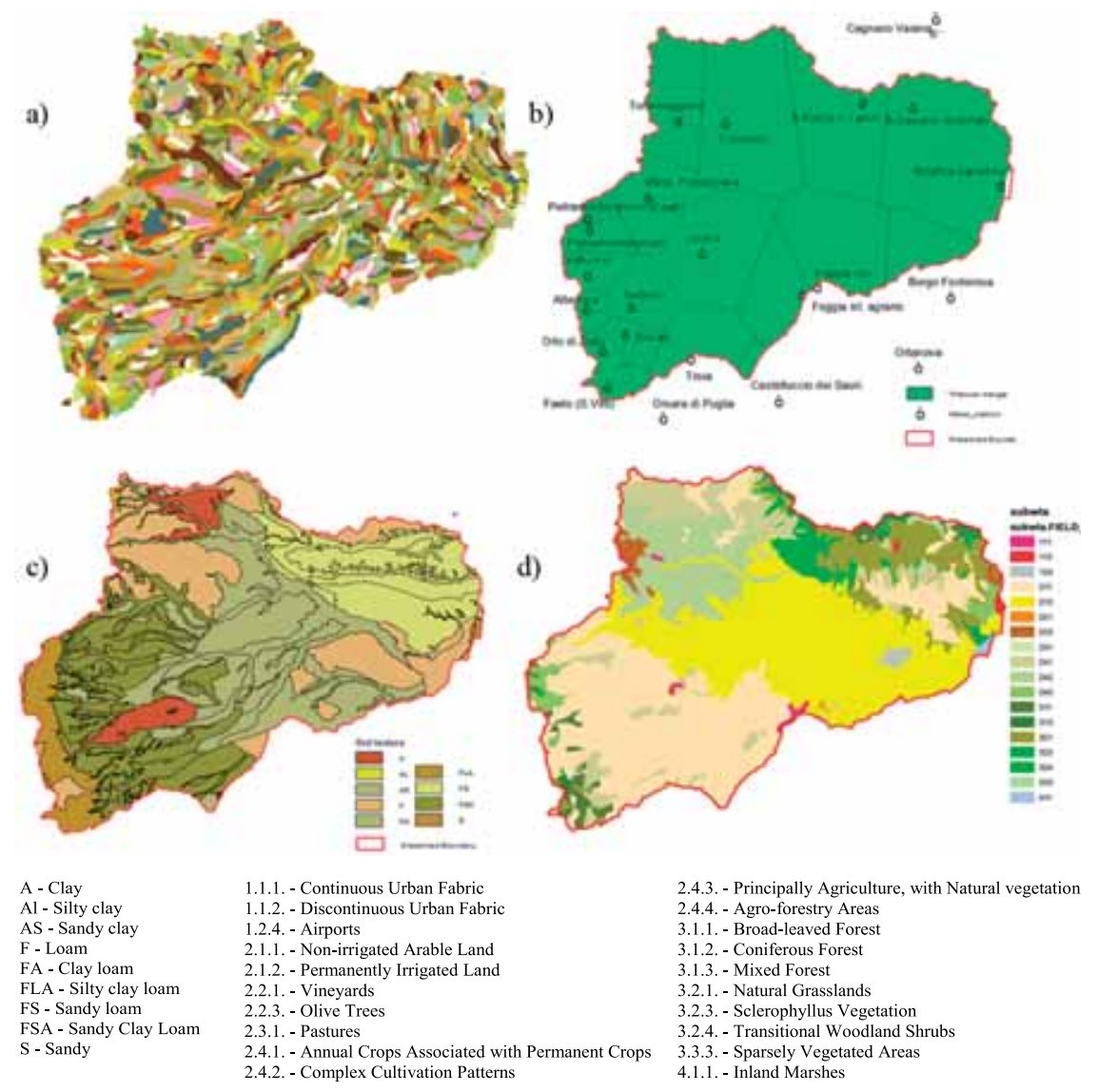

Figure 2: Candelaro watershed input dataset: (a) sub-watersheds; (b) Thiessen polygons; (c) soil texture; and (d) land-use.

A manual trial-and-error adjustment of the Curve numbers and Manning's coefficients were executed to match with the simulated and observed values. The statistical indicators used for the evaluation of the model performance are the coefficient of determination $\left(R^{2}\right)$ and the Nash-Sutcliffe model efficiency (NSE) [22]. Table 1 reports the final values of the CN coefficients.

The periods 1975-1981 for Vulgano and 1975-1978 for Salsola were used for the calibration of runoff, whereas the periods 1982-1984 for Vulgano and 1981-1982 for Salsola were used for validation (Figs. 3 and 4). The period 1973-1974 was used to initialize the model before the calibration period.

The periods 1970-1976 for Vulgano and 1970-1972 for Salsola were used for the calibration of sediment load, whereas the periods 1978-1981 for Vulgano and 1974-1979 for Salsola were used for validation (Figs. 5 and 6). The period 1968-1969 was used as a warm-up to help initializing the model before the start of the calibration period.

The summary of the statistical analysis is reported in Table 2. The indicators pointed out the good performance of the model. Figure 7 reports the simulated and observed data for the entire period (1970-1984). 
Table 1: The curve number values for each AnnAGNPS cell.

Cover type The final curve numbers for hydrologic soil groups

\begin{tabular}{lclll}
\hline & \multicolumn{1}{c}{$\mathrm{A}$} & \multicolumn{1}{c}{$\mathrm{B}$} & \multicolumn{1}{c}{ C } & \multicolumn{1}{c}{ D } \\
\hline Cropland & 70.56 & 79.38 & 86.24 & 89.18 \\
Fallow & 74.48 & 83.30 & 88.2 & 96.04 \\
Rangeland & 34.30 & 54.88 & 68.6 & 75.46 \\
Forest & 42.14 & 63.7 & 74.48 & 80.36 \\
Urban & 87.22 & 90.16 & 92.12 & 93.10 \\
Pasture & 48.02 & 67.62 & 77.42 & 82.32 \\
\hline
\end{tabular}
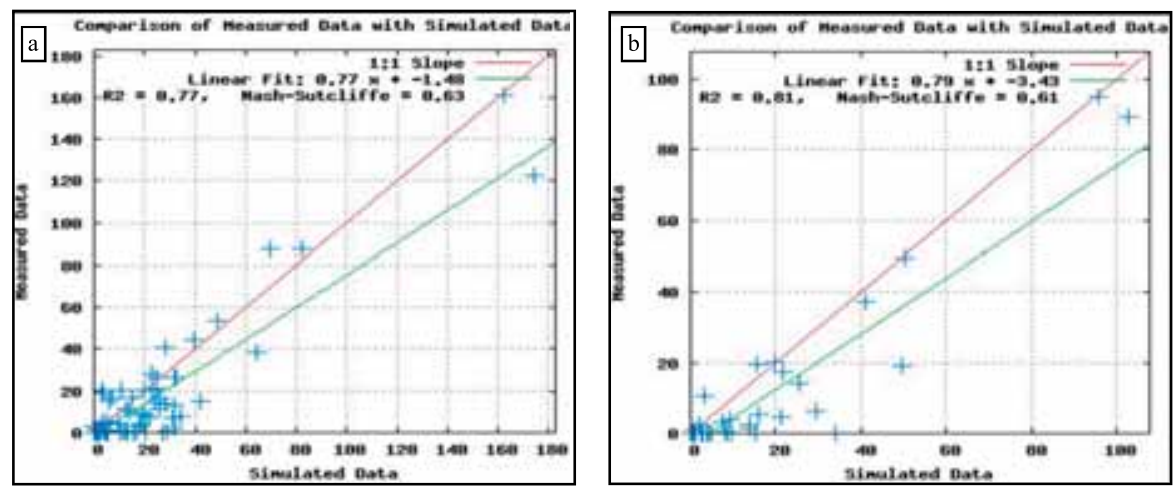

Figure 3: AnnAGNPS simulated vs. observed runoff for Vulgano in the calibration (a) and validation (b) phases.
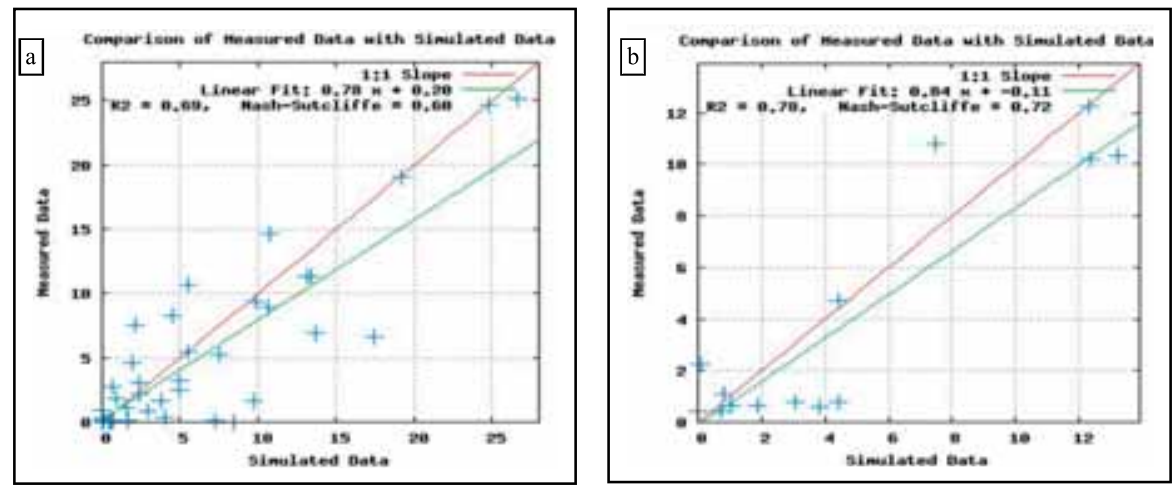

Figure 4: AnnAGNPS simulated vs. observed runoff for Salsola in the calibration (a) and validation (b) phases. 

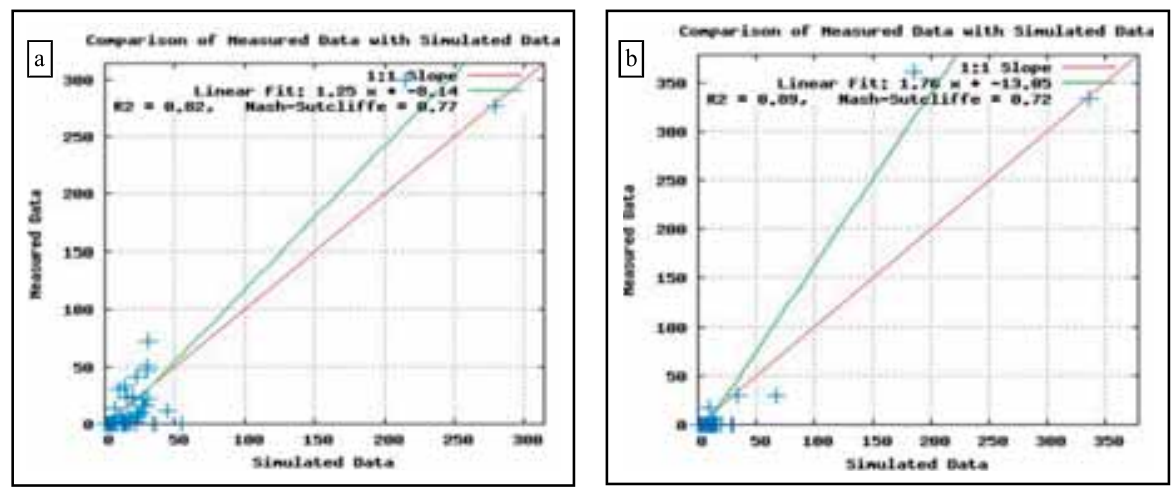

Figure 5: AnnAGNPS simulated $v s$ observed sediment load for Vulgano in the calibration (a) and validation (b) phases.
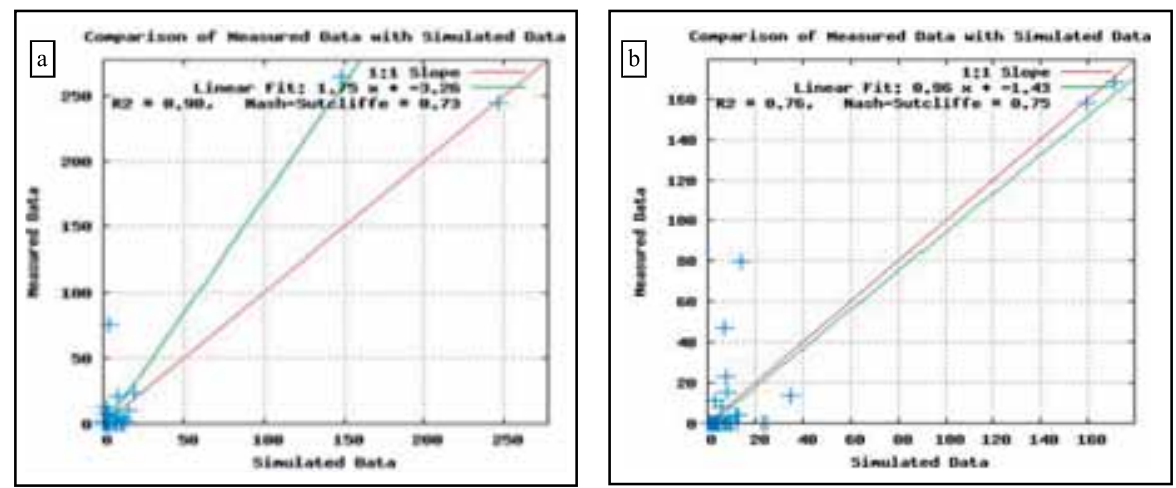

Figure 6: AnnAGNPS simulated vs. observed sediment load for Salsola in the calibration (a) and validation (b) phases.

Table 2: The summary of the statistical indicators in the calibration and validation phases.

\begin{tabular}{lccccccccc}
\hline & \multicolumn{4}{c}{ Runoff } & \multicolumn{3}{c}{ Sediment load } \\
\cline { 2 - 11 } & \multicolumn{2}{c}{ Calibration } & \multicolumn{2}{c}{ Validation } & \multicolumn{2}{c}{ Calibration } & \multicolumn{2}{c}{ Validation } \\
\cline { 2 - 11 } & NSE & $R^{2}$ & NSE & $R^{2}$ & NSE & $R^{2}$ & NSE & $R^{2}$ \\
\hline Vulgano & 0.63 & 0.77 & 0.61 & 0.81 & 0.77 & 0.82 & 0.72 & 0.89 \\
Salsola & 0.60 & 0.69 & 0.72 & 0.78 & 0.73 & 0.90 & 0.75 & 0.76 \\
\hline
\end{tabular}

\subsection{Alternative management scenarios}

The model has then been applied for a period of 24 years (1985-2008) using the parameters calibrated during the first phase of the work. The aim was to evaluate the effects of different land management options on the total sediment load at the watershed scale. The variation of 

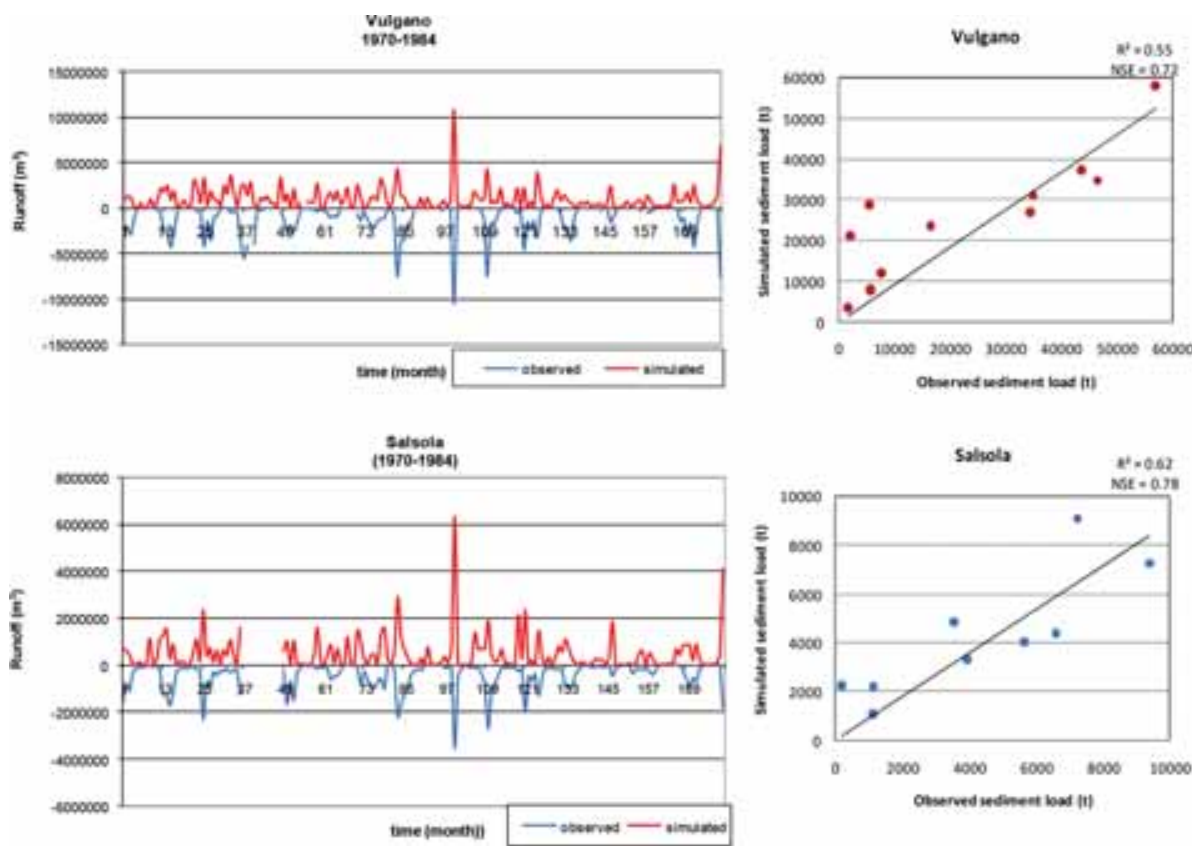

Figure 7: AnnAGNPS simulated vs. observed runoff (monthly scale) and sediment loads (yearly scale) for the period 1970-1984.

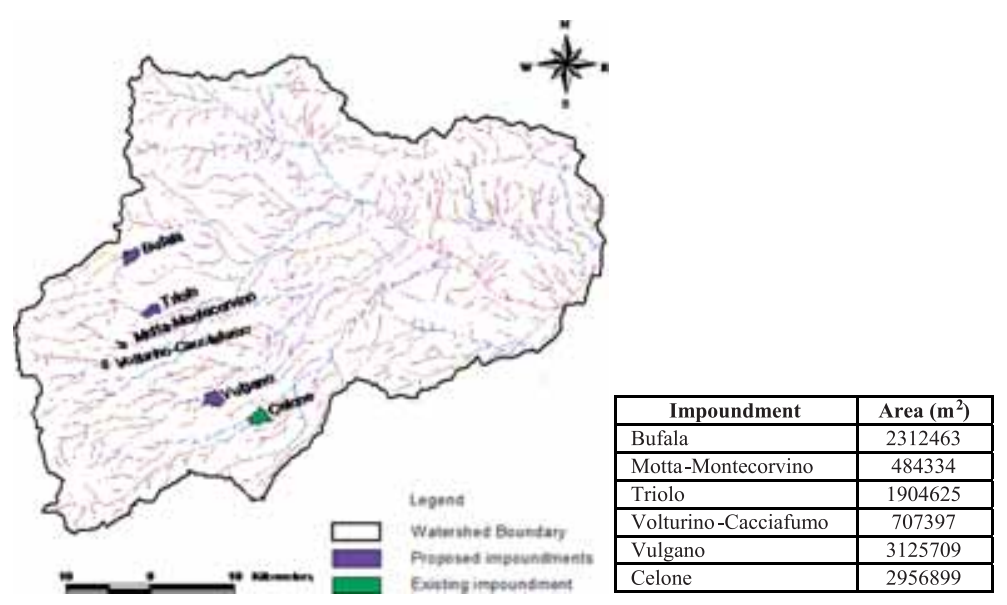

Figure 8: The location of the proposed impoundments.

the related parameters is predefined into the model. Seven combinations of land management options were considered:

- $C T$ conventional tillage;

- VS_CT vegetated streams in conventional tillage conditions;

- VS_Imp_CT vegetated streams and impoundments in conventional tillage conditions. Figure 8 shows the area and location of the proposed impoundments; 
- NTP no-till plant;

- VS_NTP vegetated streams in no-till plant conditions;

- Imp_NTP impoundments in no-till plant conditions; and

- VS_Imp_NTP vegetated streams and impoundments in no-till plant conditions.

Figure 9 shows the cumulated and average yearly sediment loads for the period 1985-2008 for each of the seven land management options. The percent variation of the sediment load is calculated considering the conventional tillage condition as a reference value. The cumulative frequency distributions $c d f_{\mathrm{s}}$ are reported in Fig. 10.
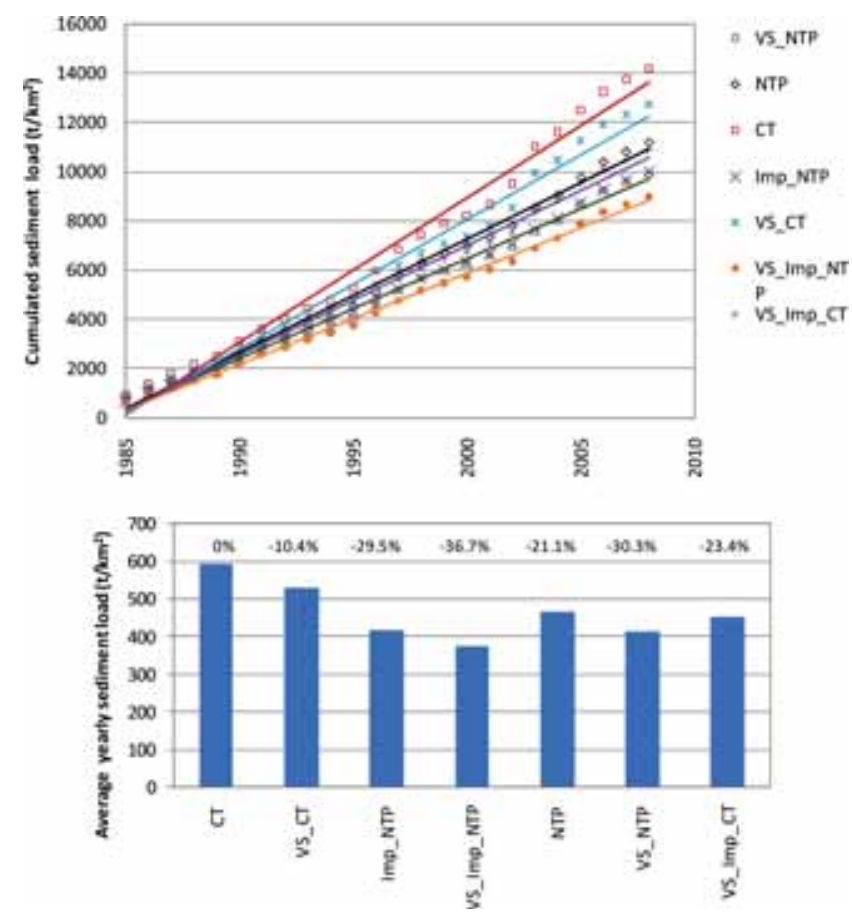

Figure 9: Cumulated and average yearly sediment loads.

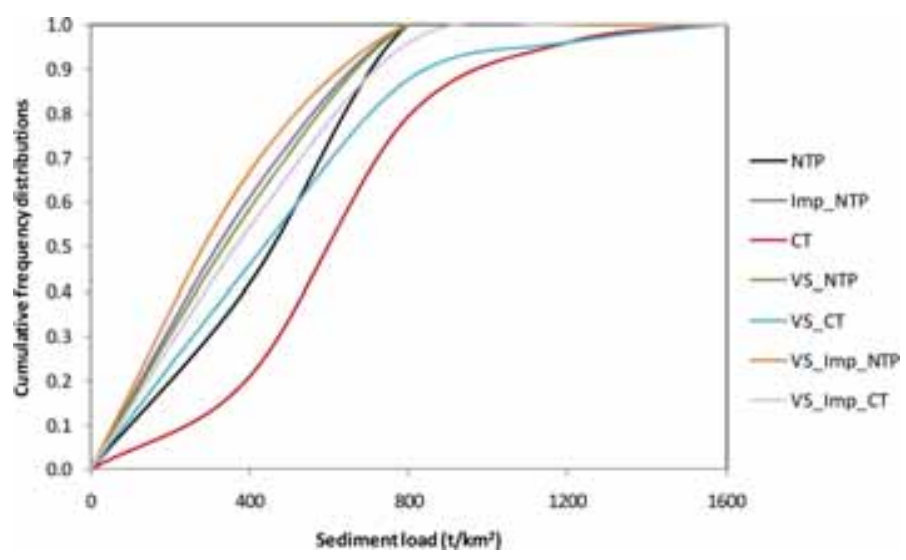

Figure 10: The cumulative frequency distributions. 
The conventional tillage provides the highest sediment load. Comparing no-till plant and conventional tillage a reduction in the sediment load of more than $20 \%$ is observed. The no-till plant $c d f$ is shifted to the left with respect to the conventional tillage for all sediment loads, but more for high values. This indicates that non-conservative agricultural practices influence sediment load, especially, during the wet periods.

In conventional tillage conditions, the use of vegetated streams determines a moderate reduction in the sediment load and this reduction is concentrated in the dry periods, as highlighted from the $c d f$ curves. The addition of impoundments gives an overall decrease of more than $20 \%$ distributed in all the periods.

In no-till plant conditions vegetated streams as well as impoundments determine a decrease of $\sim 30 \%$ with respect to the conventional tillage and their combination gives an overall reduction of $36.7 \%$. Their influence is significant in average weather periods.

\section{CONCLUSIONS}

In this study, the AnnAGNPS model was implemented to provide a basis for decision makers to plan alternative land management options and assess their impacts on runoff and sediment yield at the catchment scale. The calibration and validation phases were successful as evidenced by the reasonable match between the observed and simulated runoff and sediment yield values. The set of optimized parameters along with the other representative of the system was then used to evaluate the effects of different land management scenarios. In particular, the use of the AnnAGNPS model allowed one to quantify the relative effects on the sediment yield at the watershed outlet of the introduction of tillage in the agricultural areas, the use of hydraulic structures such as impoundments and the revegetation of the banks along the river network. It also had the capability of simulating the combined effects on the sediment yield deriving from the application of the three different scenarios. The results of the first phase showed that the AnnAGNPS model performed well in simulating runoff and sediment yield for both the Vulgano and Salsola sub-watersheds; the second phase showed that it is also a useful tool to make a sounded assessment of different land management options in the Candelaro basin. Agricultural practices have the major influence on sediment yield and the choice of conservative options gives important benefits, especially, during the wet periods. The addition of environmentally targeted options and hydraulic works also takes sediment loads at lower values in average weather conditions.

\section{REFERENCES}

[1] Beasley, D.B. \& Huggins, L.F., ANSWERS (Areal Nonpoint Source Watershed Environment Response Simulation): User's Manual, U.S. Environmental Protection Agency: Chicago, Illinois, 1982.

[2] Bingner, R. L., Theurer, F.D. \& Yuan, Y., AnnAGNPS technical processes documentation, Version 5.0, USDA- Agricultural Research Service, National Sedimentation Laboratory: Oxford, MS, 2009.

[3] Sharpley, A.N. \& Williams, J.R., EPIC-Erosion/Productivity Impact Calculator, USDA, Agricultural Research Service, Technical Bulletin No. 1768, Washington, D.C., pp. 235, 1990.

[4] Arnold, G., Srinavasan, R., Muttiah, R.S. \& Williams, J.R., Large Area Hydrologic Modeling and Assessment. Part I. Model Development. Journal of the American Water Resources Association, 34, pp. 73-89, 1998. doi: http://dx.doi.org/10.1111/j.1752-1688.1998.tb05961.x 
[5] Baginska, B., Milne-Home, W. \& Cornish, P.S., Modelling nutrient transport in Currency Creek, NSW with AnnAGNPS and PEST. Environmental Modelling \& Software, 18, pp. 801-808, 2003. doi: http://dx.doi.org/10.1016/S1364-8152(03)00079-3

[6] Sarangi, A., Cox C.A. \& Madramootoo, C.A., Evaluation of the AnnAGNPS Model for prediction of runoff and sediment yields in St. Lucia watersheds. Biosystems Engineering, 97, pp. 241-256, 2007. doi: http://dx.doi.org/10.1016/j.biosystemseng.2007.02.015

[7] Yuan, Y., Locke, M.A. \& Bingner R.L. Annualized Agricultural non-point source model application for Mississippi Delta Beasley Lake watershed conservation practices assessment. Journal of Soil and Water Conservation, 63(6), pp. 542-551, 2008. doi: http:// dx.doi.org/10.2489/jswc.63.6.542

[8] Parajuli, P.B., Nelson, N.O., Frees, L.D. \& Mankin, K.R., Comparison of AnnAGNPS and SWAT model simulation results in USDA-CEAP agricultural watersheds in southcentral Kansas. Hydrological Processes, 23(5), pp. 748-763, 2009. doi: http://dx.doi. org/10.1002/hyp.7174

[9] Yuan, Y., Bingner, R.L. \& Rebich, R.A., Evaluation of AnnAGNPS on Mississippi Delta MSEA watersheds. Transactions of the ASAE, 44(5), pp. 1183-1190, 2001.

[10] Shrestha, S., Babel Mukand, S., Das Gupta, A. \& Kazama, F., Evaluation of annualized agricultural nonpoint source model for a watershed in the Siwalik Hills of Nepal. Environmental Modelling \& Software, 21(7), pp. 961-975, 2006. doi: http://dx.doi. org/10.1016/j.envsoft.2005.04.007

[11] Licciardello, F., Zema, D.A., Zimbone, S.M. \& Bingner, R. L., Runoff and soil erosion evaluation by the AnnAGNPS model in a small Mediterranean watershed. Transactions of the American Society of Agricultural and Biological Engineers (ASABE) 50(5): pp. 1585-1593, 2007.

[12] Gentile, F., Bisantino, T. \& Trisorio Liuzzi, G., Erosion and sediment transport modeling in Northern Puglia watersheds. WIT Transaction on Engineering Sciences, 67, pp.199-212, 2010. doi: http://dx.doi.org/10.2495/DEB100171

[13] Lacombe, G., Cappelaere, B. \& Leduc, C., Hydrological impact of water and soil conservation works in the Merguellil catchment of central Tunisia. Journal of Hydrology, 359, pp. 210-224, 2008. doi: http://dx.doi.org/10.1016/j.jhydrol.2008.07.001

[14] Vache, K.B., Eilers, J.M. \& Santelmann, M.V., Water Quality Modeling of Alternative Agricultural Scenarios in the US Corn Belt. Journal of the American Water Resources Association 38 (3), pp. 773-787, 2002. doi: http://dx.doi.org/10.1111/j.1752-1688.2002. tb00996.x

[15] Penman, H.L., Natural evaporation from open water, bare soil, and grass. Proc. Royal Soc. (London), Ser. A, 193, pp. 120-145, 1948. doi: http://dx.doi.org/10.1098/ rspa.1948.0037

[16] Theurer, F.D. \& Cronshey, R.G., AnnAGNPS - Reach routing processes. Proc. of the First Federal Interagency Hydrologic Modeling Conference. Las Vegas, Nevada. April 19-23, pp. 1-25 to $1-32,1998$.

[17] Theurer, F.D. \& Clarke, C.D., Wash load component for sediment yield modeling. Proc. of the Fifth Federal Interagency Sedimentation Conference, March 18-21, Las Vegas, NV: Subcommittee on Sedimentation of the Interagency Advisory Committee on Water Data, 1, pp. 7-1 to 7-8, 1991.

[18] Yoon J., Watershed scale non-point source pollution modelling and decision support system based on a model- GIS-RDBMS linkage. Proceedings of AWRA Symposium on GIS and Water Resources, Ft Lauderale, FL, 2-16,1996. 
[19] Mohammed H., Yohannes F. \& Zeleke G., Validation of agricultural non-point source (AGNPS) pollution model in Kori watershed, South Wollo, Ethiopia. International Journal of Applied Earth Observation and Geoinformation, 6, pp. 97-109, 2004. doi: http://dx.doi.org/10.1016/j.jag.2004.08.002

[20] Bisantino T., Bingner R., Chouaib W., Gentile F. \& Trisorio Liuzzi G., Estimation of runoff, peak discharge and sediment load at the event scale in a medium-size Mediterranean watershed using the AnnAGNPS model. Land Degradration and Development, 2013. doi: http://dx.doi.org/10.1002/1dr.2213

[21] Caliandro, A., Lamaddalena, N., Stellati, M. \& Steduto, P., Caratterizzazione agroecologica della Regione Puglia in funzione della potenzialità produttiva: Progetto Acla 2, Puglia, Bari, 2005 (in italian).

[22] Nash, J.E. \& Sutcliffe, J.V., River flow forecasting through conceptual models part I A discussion of principles. Journal of Hydrology, 10, pp. 282-290, 1970. doi: http:// dx.doi.org/10.1016/0022-1694(70)90255-6

"This is a revised version of the paper published in WIT Transactions on Engineering Sciences, Vol 73, (C) 2012 WIT Press, www.witpress.com, ISSN 1743-3533 (on-line), doi: 10.2495/ DEB120101." 